Editorial Office : Faculty of Law, Andalas University

Kampus Pancasila, Jalan Pancasila Nomor 10 Padang, West Sumatera

Phone/Fax : 0751-27404 / 0751-34605

E-mail : nagarilawreview@gmail.com | Website : nalrev.fhuk.unand.ac.id

\title{
The Schorsing in Implementation of Administrative Decision that Endanger the Environment by Administrative Court
}

\author{
"Miftah Sa'ad Caniago1"
}

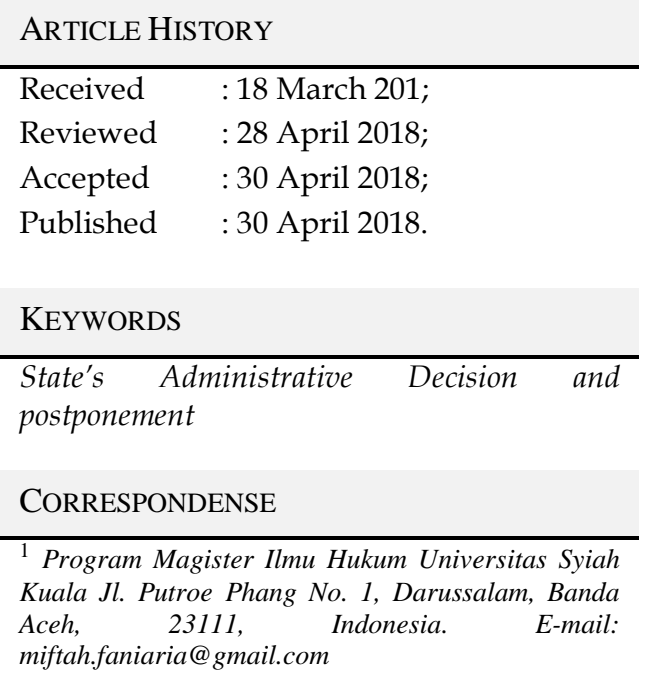

\begin{abstract}
A B S T R A C T
The postponement criteria in the implementation of KTUN (Administrative Decision) based on Article 67 of the Act Number 5, 1986 concerning the State Administrative Court (the Act of Administrative Court) merely states that such Postponement can be made if there is a very urgent circumstance which results in the plaintiff's interest to be lost if the sued state's administrative decision is still implemented. By the promulgation of the Act Number 30, 2014 on the Governance Administration, it reregulates the delay of the implementation of the decision worded in Article 65. However, there are varies in the regulation of the implementation of the such decision pursuant to Article 67, of the Act Law Number 5, 1986 concerning the State Administrative Court. In accordance with Article 65 of the Administrative Governance Act, it rules more detailed regarding the reasons for the State Administrative Court that may delay the enforcement of a Government Decree, one of which if a Government Decision or Action "has the potential to cause environmental damage" and the Court in issuing such a delay shall be in the form of a "Verdict", so that it is different from the arrangement in Article 67 of the State Administrative Judicature Law and its derivatives which stipulates that the reason for the postponement of the validity of a State Administrative Decree if there is an "urgent circumstance" issued in the form of "Stipulation".
\end{abstract}

The research shows that the Act Number 30, 2014 as a substantive law does not regulate in detailed regarding procedural law of such adjournment application, hence based on the principle of lex specialis derogat legi generali a judge has to refer to the rule on the postponement that already exist till it is enacted the new one that might accommodate the postponement implementation and it can determine that the Postponement Execution Delay a judge must view the urgency of the Decision/the Government Action might be delayed by referring to review result or auditing from auditors of the environment that has been certified by the LSK of environmental auditors that is under the Ministry of Environment, and it is not against " the public interest". 


\section{Introduction}

The Administrative Court in Indonesia is not inseparable from the mandate of state administration to give a sense of justice to the people. Administration of the State Administrative Court (Administrative Court) in Indonesia is a constitutional intention in order to provide legal protection to the people maximally. ${ }^{1}$ The legal basis for the existence of the judiciary in Indonesia can be found in Article 24 paragraph (1) and paragraph (2) of the 1945 Constitution of the State of the Republic of Indonesia (UUD 1945) after a decisive amendment: ${ }^{2}$

(1) Judicial power is an independent power to administer justice to uphold law and justice;

(2) Judicial Power shall be exercised by a Supreme Court and its subordinate courts within the general courts, the jurisdiction of the judiciary, the military court environment, the administrative court of the State, and by a Constitutional Court.

The State Administrative Court is established with the aim of fostering, perfecting and disciplining the apparatus in the field of State Administration, in order to be an efficient, effective, clean, and authoritative tool and the State Administrative Court as a place to resolve disputes or disputes between the Agency or Administrative State Enterprises with community members. In addition, the State Administrative Court is also a tool of control for State Administration Officers in performing their duties and authorities. As such, the State Administrative Court has a role in improving good governance.

The object of dispute in the Administrative Court is the State Administrative Decree (Beschikking) issued by the State Administration Officers / Officers. As mentioned in Article 1 point 9 of Law Number 51 Year 2009 regarding the Second Amendment

1 Zairin Harahap, (1997). Hukum Acara Peradilan Tata Usaha Negara. Jakarta: Raja Grafindo Persada, p. 19

2 R. Wiyono, (2010). Hukum Acara Peradilan Tata Usaha Negara. Edisi Kedua. Jakarta: Sinar Grafika, p. 1 to Law Number 5 Year 1986 regarding State Administrative Court. While the acts of other State Administration Bodies / Officers both material deeds (daad material) and the issuance of regulation (regeling) are respectively the jurisdiction of the General Courts and the Supreme Court.

Prior to 1990, administrative or administrative matters entered into the competence of civil courts or quasi-administrative justice institutions such as the Tax Advisory Board, the Doane Commission, the Assembly or the Aviation Council or the Labor Dispute Committee. In addition to the civic administrative and quasi administrative rechtsspraak courts, the state administrative dispute is also resolved through administrative appeals to the office or official environment. ${ }^{3}$

The characteristic of the Procedural Law of State Administration Courts lies in the underlying legal principles, which are: 4

1. Principle of Prediction Rechtmatig (vermoeden van rechtmatigheid $=$ praesumptio iustae causa). This principle implies that every act of the ruler should always be considered rechtmatig until there is a cancellation. With this principle, the lawsuit does not delay the implementation of the defendant KTUN;

2. The Principle of Free Proof

The judge who establishes the burden of proof;

3. Principle of Judge's Activity (dominus litis)

The activeness of the judge is intended to offset the position of the parties because the defendant is the State Administrative Officer while the Plaintiff is a civil person or legal entity;

4. Judgment Principle of the Court Has Strength Binding "Erga Omnes"

Based on the Presupposes Rechmatiq / Praesumptio Iustae Causa Principles stating that the State Administrative Decision (KTUN) should be considered legally valid until the Court's

${ }^{3}$ Bagir Manan (2004). Paper. Medan: Sambutan Ketua Mahkamah Agung padaPertemuan Peradilan Tata Usaha Negara seluruh Indonesia.

4 Philipus M. Hadjon, dkk. (2005). Pengantar Hukum Administrasi Negara. Yogyakarta: Gadjah Mada University Press, p. 313 
decision states otherwise, this is for the task of the government especially in order to provide protection, public services service) and realize the welfare for the community can walk.

Article 67 of the Law of the Republic of Indonesia Number 51 Year 2009 Concerning the Second Amendment to Law Number 5 Year 1986 concerning State Administrative Court further reinforces the principle of Presupposes Rechmatiq / Praesumptio Iustae Causa, that as long as it has not been decided by the court, the Decision of the State Administration issued by a State Administrative body or officer, shall be deemed legally valid. The principle is also as a protection for State Administrative Officers in issuing policies so that no obstacles in the implementation of tasks, so that the smooth task is not disturbed.

In certain cases or circumstances, the plaintiff may file an application so that during the course of the trial, the said state administrative decision may be ordered to postpone its implementation or to postpone the execution of the decision of the state administrative officer. This is in accordance with the provisions of Article 67 Paragraph (2) and Paragraph (4) Sub-Paragraph a of Law Number 5 Year 1986 regarding the State Administrative Court (State Administrative Judicature Act) which states that: "Plaintiffs may apply for The Administrative Decision of the State was postponed during the administrative dispute of the State Administration disputes, until a court decision has obtained a permanent legal force ". The application for postponement as referred to in paragraph (2) may be granted only if there is a very urgent circumstance resulting in the interests of the plaintiff to be severely impaired if the applicable State Administrative Decree is still exercised.

The grammatical interpretation of the correlation of article 67 verses (1) and (2) gives the impression that there is a contradiction between verse (1) and (2). If article 67 Paragraph (1) prohibits the postponement of the implementation of KTUN, it turns out that article 67 paragraph (2) actually opens up opportunities for delay in the implementation of

5 W. Riawan Tjandra. (2005). Hukum Acara Peradilan Tata Usaha Negara. Edisi Revisi. Yogyakarta: Universitas Atma Jaya, p. 77
KTUN. However, by using a systematic interpretation it can be analyzed that the relationship between the two verses of the chapter is the relationship between the general principle, the algemene beginsel with the special principle, the bijzondere beginsel. In the special circumstances provided for in article 67 paragraph (4), a special principle embodied in article 67 paragraph (2) which excludes the general principle (article 67 paragraph 1) which contains the principle of legitimate presumption, in order to provide protection against the interests of the plaintiff. ${ }^{5}$

Examples of the urgent circumstances mentioned in Article 67 paragraph (2) and paragraph (4) sub-paragraph a of the State Administrative Justice Act are if there is a person who owns a building established not having Building Permit (IMB) from the Regent / Mayor so that the Mayor ordered the building to be demolished through a unloading order, then the person could sue the Regent / Mayor to test the unloading order to the State Administrative Court (PTUN) in terms of authority, Procedure and Substance of the issuance, to avoid the dismantling of that person's property, the Court may suspend the dismantling until the Court's Decision.

In terms of legal protection in concrete circumstances the presumption is abolished (check the explanation of article 67). Under certain circumstances, the plaintiff may file an application during the process, the requested KTUN is ordered to be postponed. Thus, regarding the postponement of disputed KTUN execution during the ongoing inspection process, it must be requested or filed with the Court (can not be postponed automatically due to court proceedings). ${ }^{6}$

Article 67, paragraph 2, thereby granting the plaintiff the right to "under certain circumstances" (article 67, paragraph $4 \mathrm{sub}$ a) is permitted to deviate from the presumption of rechtmatig principle contained in article 67 paragraph 1. Criteria for postponement of the implementation of KTUN in the law shall only be mentioned there is a very urgent situation

${ }^{6}$ Ibid., p. 78 
which results in the plaintiff's interest to feel aggrieved if the claimed KTUN is still being implemented (article 67 paragraph 4 sub a). The term "urgent circumstances" in article 67 is explained that if the losses to be suffered by the plaintiff will be very unbalanced compared to the benefits for the interest that will be protected by the implementation of the Administrative Decree. Therefore, to assess the existence of "very urgent circumstances" should be viewed casuistically based on the concrete facts occurring and the possibility of losses that will arise must be assessed objectively. ${ }^{7}$

On October 17, 2014 with the issuance of Law Number 30 Year 2014 About Government Administration (Administration Act), the more developed the authority of the State Administrative Court. The birth of Government Administration Law in addition to expected to be the basis and legal umbrella for the Agency and / or Government Officials in carrying out the tasks of governance is also expected to guarantee basic rights and provide protection for the citizens. Citizens may file a lawsuit against the Decision and / or the Acts of the Agency and / or Government Officials to the State Administrative Court because this law constitutes the material law of the State Administrative Court system. ${ }^{8}$

Article 65 of Law Number 30 Year 2014 on Government Administration is also stipulated concerning the suspension of the Decision of the State Administration Board / Administrative Officer (the government) is also regulated in, as it reads:

(1) Decisions that have been determined can not be postponed, unless potentially causing:

a. State losses;

b. Environmental damage; and/ or

c. Social conflict.

(2) The postponement of the decision as referred to in paragraph (1) may be made by:

7 Ibid., p. 78-79

8 Penjelasan Umum Undang Undang Nomor 30 Tahun 2014 Tentang Administrasi Pemerintahan, dan dapat dilihat juga dalam Rapat Kerja antara DPR RI Menteri Dalam Negeri, Menteri
a. Government Official establishing a Decision; and / or
b. Officer's Officer.

(3) Delayed Decisions may be made on the basis of:
a. Request of the relevant Government Official; or
b. Court ruling.

Under these provisions, the consideration in the postponement is no longer on the grounds of "urgent circumstances" but has been determined that if such a State Administrative Decision has the potential to cause State Losses, environmental damage and social conflict. The stipulation also stipulates that such a delay may be made by a Government Official who stipulates a Decision or Officer of Officials who stipulates that Decision, one of which is based on a Court Decision. This is in contrast to the provisions stipulated in Article 67 of Law Number 5 Year 1986 concerning the State Administrative Court which states that the delay may be filed by the justice seekers to the State Administrative Court by filing a petition on the grounds of urgent circumstances that may harm the interests Plaintiffs are severely restored if the State Administrative Decree issued by the State Administration Officers / Officers is still in place so that the State Administrative Decree issued by the State Administration Officers / Officers must be postponed for the determination of the Administrative Court of the State.

\section{Problem Statements}

Based on the background as stated above, then the formulation of the problem in this study are:

1. What is the mechanism of Suspension / Schorsing in the State Administrative Court before and after the issuance of article 65 of Law Number 30 Year 2014 on government administration?

2. What are the criteria used to be declared a Decree of the State Administration Official (KTUN) to have the potential to cause Environmental Damage and may be

Pemberdayaan Aparatur Negara, Menteri Hukum dan Hak Asasi Manusia, dan Menteri Keuangan, pada hari Selasa, tanggal 20 Mei 2014 dalam Sekretaris Jenderal DPR RI, Risalah Undang-Undang Administrasi Pemerintahan, p. 5 
postponed by the Administrative Court of the State?

\section{Method}

Research methods are procedures or means of acquiring correct knowledge or truth through systematic steps. The method used in this thesis research is the normative juridical research method. The normative juridical research type is a study that examines the study of documents, using a variety of secondary data such as Legislation, legal theory and some expert opinions. This study uses qualitative analysis that is by explaining the existing data with words or statements not with numbers.

\subsection{Type and Research Approach}

Thesis as a scientific work must be outlined firmly, clearly and systematically based on reliable data of the truth so that before writing, it required the existence of research. Research is a scientific activity related to analysis and construction that is done methodologically, systematically and consistently. In writing this thesis the author uses the approach method of legislation. In this thesis used normative juridical Types and approaches.

The things studied in normative legal research include several things such as Legal Principles, Legal Systematics, Standard of Law Synchronization, Comparative Law.

In Normative Law research there are several sources of law namely:

a. The primary sources of law used in this study are the prevailing laws and regulations, such as Law Number 5 of 1986 on State Administrative Courts, Law Number 31 Year 1999 on the Eradication of Corruption, Law Number 9 Year 2004 regarding Amendment to Law Number 5 Year 1986 regarding State Administrative Court, Law Number 30 Year 2014 on Government Administration, and Decisions of the State Administrative Court.

b. Sources of secondary law in this study are in the form of legal literature of State Administration, Procedural Law of State Administration Court, Criminal Law, and other materials especially related to the problem to be studied. c. Tertiary legal sources used in this study are taken from dictionaries, magazines, newspapers, the Internet to support information in research.

\subsection{Source and Data Analysis Technique}

The research data that has been collected is done by qualitative normative analysis. The anlysis is considered because of the rules that exist as positive law. Qualitative method is provided because it is an analysis of data derived from the information of interview results described by the respondents, presented descriptively. Thus an analysis of data without using formulas and figures and the results of author analysis is qualitative.

Sources of data used in the writing of this thesis are:

a. Library research, which will be conducted through the collection of primary legal materials in the form of legislation that is Law Number 30 Year 2014 About Government Administration especially Article 65 on the postponement of the implementation of the State Administrative Decision (KTUN) by the State Administrative Court;

b. Data collection techniques used in this study is literature study.

Based on the scope, objectives and approaches in this study to obtain data in accordance with what is needed then the data collection techniques used is literature study, which consists of Law Number 30 Year 2014 on Government Administration, related regulations, books and writings and documents that closely relate to the issues discussed in this study.

2.3 Data Analysis

The data obtained will be collected and compiled, then done the editing process is to examine and examine the data obtained to ensure whether the data obtained is correct and can be accounted for according to the fact (accurate source) with the consideration of reliability (validity) and validity (validity).

Then the data has been collected in the analysis qualitatively, then to analyze the data obtained by using inductive method, which is trying to find the rules, values and legal norms contained in the library, which 
then conducted the discussion. Based on the results of the discussion then taken the conclusion as an answer to the problem under study.

\section{The Results}

3.1. Suspension / Schorsing Mechanisms In State Administrative Courts After Issuance of Article 65 of Law Number 30 Year 2014 About Government Administration

The process of postponing the implementation of the State Administration Decree in the Government Administration Act is stipulated in Article 65 which states that:

(1) Decisions that have been determined can not be postponed, unless potentially causing:
a. State losses;
b. Environmental damage; and/ or
c. Social conflict.

(2) The postponement of the decision as referred to in paragraph (1) may be made by: a. Government Official establishing a Decision; and / or

b. Officer's Officer.

(3) Delayed Decisions may be made on the basis of:

a. Request of the relevant Government Official; or

b. Court ruling.

Based on these provisions, the delay in the implementation of the Decision of State Administration may be postponed on the grounds of 3 matters that if the State Administrative Decision has the potential to cause State Losses, Environmental Damage and Social Conflict so that if related to the provisions of Article 67 of Law Number 5 Year 1986 there is a very the fundamental reason for such a Decision of State Administration may be postponed by the State Administrative Court. For more details about the difference in the Delays / Schorsing arrangements set forth in the State Administrative Justice Act with those stipulated in the Government Administration Act we can see the following table:

Table 1. Differences Postponement in Article 67 of the UU No. 5/1986 with the Article 65 of the UU No. 30/2014

\begin{tabular}{|c|c|c|}
\hline Differences & UU No 5 Year 1986 & UU No 30 Year 2014 \\
\hline Form & Request & Gugatan \\
\hline Product of Law & Determination & Putusan \\
\hline $\begin{array}{c}\text { The organizer who can } \\
\text { do delay }\end{array}$ & $\begin{array}{l}\text { Agency / Official issuing the } \\
\text { Decision of State } \\
\text { Administration }\end{array}$ & $\begin{array}{l}\text { Agency / Official issuing the State } \\
\text { Administrative Decision and / or } \\
\text { Officer's Officials }\end{array}$ \\
\hline Reasons for delay & $\begin{array}{l}\text { 1. The losses to be suffered by } \\
\text { the Plaintiff will be very } \\
\text { unbalanced compared to the } \\
\text { benefits for the interests to be } \\
\text { protected by the execution of } \\
\text { the state administrative } \\
\text { decisions } \\
\text { 2. The implementation of the } \\
\text { defendant's state } \\
\text { administrative decision has } \\
\text { nothing to do with the public } \\
\text { interest in the framework of } \\
\text { development }\end{array}$ & $\begin{array}{l}\text { Potentially caused: } \\
\text { 1. State losses } \\
\text { 2. Environmental damage } \\
\text { 3. Social conflict }\end{array}$ \\
\hline
\end{tabular}


According to Table 1, to differences in the regulation of the reasons for the postponement of a State Administrative Decision in Article 65 of Law Number 30 Year 2014 also regulates the legal products produced or issued by the State Administrative Court that is in the form of Court Decision. This is in stark contrast to the legal products that are issued by the State Administrative Court concerning the Postponement of the Administrative Decision of the State stipulated in the provisions of Article 67 of Law Number 5 Year 1986 concerning the State Administrative Court that is in the form of Stipulation.

Under the provisions of Article 65 of the Administrative Act, it has also been fully regulated on who should postpone a government decision that is applicable by Government Officials who stipulates the Decision and may also be executed by the Officer of the Officer issuing the Administrative Decision. This is more complete than the arrangement set forth in Article 67 of the State Administrative Justice Law which only regulates the reasons for such a Decision of State Administration may be postponed or not. Article 65 of the Administrative Government Law also provides for the implementation of such delay can be made on the request of the relevant Government Official and Court Decision, but the Arrangement of the State Administrative Decree in Article 65 of the Administration Law does not stipulate clearly the mechanism or

procedure way of attorney in the State Administrative Court, this is the same as the postponement stipulated in Article 67 of the Constitution Law. However, the postponement of Article 67 of the Act has been regulated further with the internal regulations of the Supreme Court, while for the provisions stipulated in the Government Administration Act there is no rule of conduct.

Based on Article 65 of the Administrative Administration Law, the Delays Process of the Implementation of the Decision of State Administration is as follows:

\subsubsection{Submission of Delay}

${ }^{9}$ Sudikno Mertokusumo. (2002). Hukum Acara Perdata Indonesia. Edisi VI. Yogyakarta: Liberty, p. 202 a. Who has the right to file a Postponement Article 65 of the Administrative Administration Act does not expressly set forth anyone who may file a Postponement to the State Administrative Court under that provision. So that the author remains guided by the provisions of Article 67 of the Law of the State Administrative Court which is entitled is the Plaintiff who filed a lawsuit to the State Administrative Court to file the procrastination on the implementation of the Decision / Action of the State Administration Agency / Officer. A request for suspension of a State Administrative Decree may be filed at once in a suit or may be filed separately at the same time as the claim is filed or at the latest when the Reply is filed. Therefore, if there is a Claim to the State Administrative Court of the Plaintiff, it may postpone the implementation of Decision/Action from the Governing Body/Officer based on the above conditions.

b. Forms of Postponement Submission

The Form of Submission of Delays to the State Administrative Court under the provisions of Article 65 of the Administrative Administration Law is not clearly regulated on whether to file an Application or through a Claim. However, when viewed thoroughly about the contents of the provision referred to in paragraph (3) stating that the decision can be made one of them based on Court Decisions. Based on these provisions it is clear that if the legal product produced by the State Administrative Court with the submission of an award against the validity of a state administration decision filed by the justice seekers is the Court Decision.

According to Sudikno Mertokusumo, the verdict is a statement which the judge, as a state official authorized for it, is spoken in court and aims to end or settle a case or dispute of the parties. Not only the pronounced so-called verdicts, but also the statements written in the form and then spoken by the judge in the hearing. ${ }^{9}$ In addition, the ruling is also interpreted as a judge's statement in response to the litigation 
and disputes of the litigants, which are based on evidence in the hearing. At least that's the verdict interpreted by Hari Sasangka in his Law of Evidence. ${ }^{10}$

According to Mukti Arto the ruling is the revelation of a judge which is poured in written form and spoken by the judge in the hearing open to the public, as a result of the examination of the lawsuit case (kontentius). ${ }^{11}$ According to $M$. Yahya Harahap, the difference between contestation lawsuit and volunteer lawsuit is that if the case of contemporary form (countentieuse rechtpraak contentious juridiction) has the following characteristics:

1) In the form of a dispute or a party matter;

2) There is a Plaintiff party acting to file a lawsuit against the defendant;

3) The process of examination takes place contradictory (contadictoir) namely the plaintiff and the defendant has the right to refute based on the principle of alteram partem alteram. ${ }^{12}$

While the typical application or voluntary lawsuit is:

1) Issues posed are of one party interest only (for the benefit of one party only);

2) Issues requested for adjustment to the District Court in principle without dispute with other parties (without dispute or differences with another party);

3) No other person or third party is withdrawn as an opponent, but is an absolute one (ex patre)..$^{13}$

Determination of postponement is a legal product born from the application but in this case there is a State Administration dispute, so it differs from the petition in the civil procedure proceedings in the General Courts or in the Religious Courts, where in the civil procedure the petition is purely an application to obtain legalization of the rights of the applicant and no party to the dispute.

${ }^{10}$ Hari Sasangka (2005). Hukum Pembuktian. Bandung: Mandar Maju, p. 140

11 Mukti Arto. (1996). Praktek Perkara Perdata Pada Pengadilan Agama. Yogyakarta: Pustaka Pelajar, p. 168
Based on the interpretation of legislation of lex specialis derogat legi generali which states the rule of law, it can exclusively rule out the common law. In this case the Government Administration Law is a general legal rule governing Governmental Officials / Officials and constitutes a material law for the State Administrative Court, whereas the State Administrative Justice Act is a formal Act to defend the law of the material, so in the opinion the author who becomes specialist (special law) in the law in the State Administrative Court is the State Administrative Justice Act, so that the implementation mechanism of the delay by the State Administrative Court under the Government Administration Act must remain based on the State Administrative Justice Act , then the court ruling referred to in the Law on Administration of Government shall re-refer to Article 67 of the State Administrative Judicature Law, namely that the filing must be in the form of a petition and a legal product issued by the Court shall be in the form of a decision. Although these rules are not fully able to accommodate the needs referred to in the Government Administration Act because there are additional reasons for a Government Decree may be postponed, but they can still be used until the Supreme Court issues new rules to regulate them, whether in the form of Supreme Court Regulation (PERMA) or other Supreme Court rules.

\subsubsection{Requirements for Postponement Submission}

The postponement under Article 65 of the Government Administration Law of a Decision or Action of such Governing Body / Official may be postponed if the Decision / Action of the Governing Body / Official is potentially damaging to the state, environmental damage and social conflict. According to the author's opinion, although the conditions set forth in the Article only regulate 3 (three) things, but

12 M. Yahya Harahap. (2006). Ruang Lingkup Permasalahan Eksekusi Bidang Perdata. Edisi Kedua. Jakarta Sinar Grafika.

13 Ibid. 
we can not eliminate the conditions set forth in Article 67 of the State Administrative Justice Act that there is a very urgent circumstance that resulted in interest the plaintiff is severely disadvantaged, if the TUN's decision to be sued is still exercised and no public interest exists upon which the said TUN's Decree is issued. ${ }^{14}$ This is in the opinion of the author because the three conditions in the Administrative Act is a very urgent circumstance as intended in Article 67 Paragraph (4) letter a of the State Administrative Justice Act. However, the urgency in the Law on Administration of Government is made more concrete that directly states if the Decision / Action Body / Official Order has the potential to cause losses of the state, environmental damage and social conflict. If these three conditions are proven, it is urgent to undertake the implementation of such decisions / actions to protect the wider public interests that are caused by potential state losses, environmental damage or social conflict.

The discrepancies contained in the postponement conditions provided for in Article 65 of the Administrative Administration Law with the conditions of the postponed delays in the provisions of Article 67 of the Workforce Act are contradictory, since in the provisions of Article 67 of the Act on the Conflict the is protected against losses to be experienced by the Plaintiff on the issuance of a State Administrative Decree while under the provisions of Article 65 of the Administrative Administration Law the protection of such delays to a wider impact shall be to the public at large such as the potential loss of the state, environmental damage and so that the authors argue that the existence of Article 65 of the Administrative Administration Law is not contrary to the postponement provisions set forth in Article 67 of the Act on Peratun, since the thing protected here is very different and Article 65 of the Administrative and Administrative Law at increasing the requirements of a Decree of State Administration may be postponed its enforceability in order to protect the public at large from Government decisions that potentially cause state losses, environmental damage and social conflicts.

\subsection{The criteria used to be declared a State Administrative Decision (KTUN) has the potential to cause Environmental Damage and may be postponed by the Administrative Court of the State.}

The provisions of article 65 paragraph (3) of the Administrative Act of the State Administrative Decree may be postponed to be effected by the request of the relevant Government Official or also based on the Court's Decision. "Under this provision, the postponement of the implementation of the Decision of State Administration is not only applicable based on court decision but can also be executed on the request of the relevant Government Official. Decision of the Court referred to in the provisions of article 65 of the Administrative Administration Act is a decision of the State Administrative Court, this can be seen in Article 1 number 18 of the Administrative Law which states that the Court is the State Administrative Court.

The criteria used to be declared a State Administrative Decision has the potential to incur State Losses and may be postponed by the State Administrative Court not regulated either in the Administrative Administration Act or in the rules of implementing regulations governing the Government Administration Act, so the authors argue that to determine whether a decision / action made by the Agency / Government Official can be postponed its validity because the decision / action sued has the potential to cause environmental damage that is: 
a. The decision / action in requesting such a delay must be challenged in the State Administrative Court. Citizens may apply for postponement against the Decision or Action of the Government to the State Administrative Court in connection with the environment if the citizen has filed a lawsuit to the State Administrative Court. This relates to the interests of the citizens in delaying the execution of such Government Decisions or Acts.

b. The judge should see the urgency of a Government Decision or Action to be postponed.

The judge may request assistance to the competent agencies to calculate / audit for the extent of the environmental damage caused by the decision / Action issued by the Government that has issued environmental permits to the companies. Based on Article 51 Paragraph (2) UUPLH of the Ministry of Environment through Environmental Competency Certification Institution (LSK) has been certified to the Environmental Auditors. The judge may request opinions or data that are related to the results of his / her audit of the environmental issues that are being disputed in the Administrative Court of the State.

Such Government Decisions / Acts are not included in the Public Interest in the framework of Development. The concept of "public interest" even though it has been interpreted authentically in the elucidation of Article by Article in Law Number 5 of 1986, such as the Elucidation of Article 49 stating: "The meaning of" public interest "is the interest of the nation and state and / / or development interest in accordance with applicable laws and regulations. Furthermore, Article 136 states the meaning of "Public Interests". In the explanation of this Article is only seen in terms of whether or not a case should take precedence, for example because the case concerned attracts attention or related to other cases so it is deemed necessary to be checked immediately. The authorities decide that a matter of public interest and that it should take precedence. Understanding and criteria of Public Interest in various positive laws in Indonesia according to the author is an elastic term, because it can be defined vary depending on the circumstances and interpretive point of view, so that the regulation of the public interest should be regulated in a separate law wet) is not inserted in the various deeds (in de wet) as it is now so that the definition and criteria of the public interest do not make a difference.

\section{Conclusion}

1. The postponement mechanism in the State Administrative Court in the presence of Article 65 of Law Number 30 Year 2014 concerning the Administration of the Government shall continue to apply the rules contained in Article 67 of Law Number 5 Year 1986 concerning the State Administrative Court and derivative rules regulating further concerning the determination of pens issued by the Supreme Court and the existence of Article 65 of Law Number 30 Year 2014 concerning the Administration of Governments shall not remove the postponement arrangements provided for in Article 67 of Law Number 5 Year 1986 concerning the State Administrative Court.

2. Criteria to be said that a Decision of State / Government Effect that has the potential to cause Environmental Damage and may be postponed by the State Administrative Court if the Plaintiff has filed a lawsuit to the State Administrative Court on Government Decisions / Action relating to the environment. In determining the Proposal of Suspension the Judge shall continue to see the urgency of such Government Decisions / Acts may be postponed by guiding the results of audits or audits from certified environmental auditors, and not contrary to "Public Interest".

\section{Acknowledgments}

All praise and gratitude authors say the presence of Allah SWT, for the blessing and grace of His grace so that the writer is able to finish writing this thesis. Salawat and greetings of the writer served to the Prophet Muhammad SAW.

On this occasion the author would like to thank the greatest to the honorable:

1. Dr. Efendi, S.H., M.Si., as supervisor

2. Dr. Mahdi Syahbandir, S.H., M.Hum., as cosupervisor 
3. The Head of Department of Master Program in Law, The Faculty of Law, Syiah Kuala University, and all staff.

4. The Dean of Faculty of Law, Syiah Kuala University, and all staff.

5. Rector of Syiah Kuala University and all staff.

6. Lectures of Department of Master Program in Law, The Faculty of Law, Syiah Kuala University, who has provided guidance and stock of science as long as the writers follow the lectures.

7. Maftuh Efendi, S.H., M.H., dan Dr. Teguh Satya Bhakti, S.H., M.H., Hakim Yustisial in the Supreme Court.

8. Chairman, Representatives and colleagues of the Judge, as well as all employees of the State Administrative Court of Banda Aceh. In particular, this thesis is dedicated to my beloved wife, Fani Aria, S.H., M.Kn., who always gives encouragement, and sacrifice to the writer both morally and materially, and prayer always accompany every step of life journey writer. The author also expressed his greatest respect and gratitude for his beloved father and Mama, H. Masruddin Caniago, S.H., M.H., and Hj. Helmiati Aziz, AM.Keb, mother-in-law Hj. Netty Herawati, Brother and brother-in-law in Padang, as well as beloved brothers, Ismun Andi Wahyuni, S.H., M.Kn and Ade Yulina Mursyidah Saad.

Special thank to all friends of class 2015 in the Master in Law of Law Faculty of Syiah Kuala University, and all those who can not mention one by one author. Thank you very much for the help that has been given to the author so far.

\section{References}

\section{A. Book}

Hari Sasangka (2005). Hukum Pembuktian. Bandung: Mandar Maju.

M. Yahya Harahap. (2006). Ruang Lingkup Permasalahan Eksekusi Bidang Perdata. Edisi Kedua. Jakarta Sinar Grafika.

Mukti Arto. (1996). Praktek Perkara Perdata Pada Pengadilan Agama. Yogyakarta: Pustaka Pelajar.
Philipus M. Hadjon, dkk. (2005). Pengantar Hukum Administrasi Negara. Yogyakarta: Gadjah Mada University Press.

R. Wiyono, (2010). Hukum Acara Peradilan Tata Usaha Negara. Edisi Kedua. Jakarta: Sinar Grafika, p. 1

Sekretaris Jenderal DPR RI (2014). Risalah Undang-Undang Administrasi

Pemerintahan. Jakarta.

Soemaryono dan Erliyana. (1999).

Tuntunan Praktik Beracara di

Peradilan Tata Usaha Negara. Jakarta:

PT. Primamedia Pustaka.

Sudikno Mertokusumo. (2002). Hukum Acara Perdata Indonesia. Edisi VI. Yogyakarta: Liberty.

W. Riawan Tjandra. (2005). Hukum Acara Peradilan Tata Usaha Negara. Edisi Revisi. Yogyakarta: Universitas Atma Jaya.

Zairin Harahap, (1997). Hukum Acara Peradilan Tata Usaha Negara. Jakarta: Raja Grafindo Persada.

\section{B. Paper}

Bagir Manan (2004). Paper. Medan: Sambutan Ketua Mahkamah Agung padaPertemuan Peradilan Tata Usaha Negara seluruh Indonesia.

\section{Legislation and Regulation}

Undang-Undang Dasar Negara Republik Indonesia Tahun 1945

Undang-Undang Nomor 5 Tahun 1986 tentang Peradilan Tata Usaha Negara (LNRI Tahun 1986 Nomor 77, TLNRI Nomor 3344)

Undang-Undang Nomor 9 Tahun 2004 tentang Perubahan Atas UndangUndang Nomor 5 Tahun1986 tentang Peradilan Tata Usaha Negara (LNRI Tahun 2004 Nomor 35, TLNRI Nomor 4380)

Undang-Undang Nomor 32 Tahun 2009 tentang Perlindungaan dan Pengelolaan 
Lingkungan Hidup (LNRI Tahun 2009 Nomor 140, TLNRI Nomor 5059)

Undang-Undang Nomor 51 Tahun 2009 tentang Perubahan Kedua Atas Undang-Undang Nomor 5 Tahun 1986 Tentang Peradilan Tata Usaha Negara. (LNRI Tahun 2009 Nomor 160, TLNRI Nomor 5079)
Undang-Undang Nomor 30 Tahun 2014 tentang Administrasi Pemerintahan (LNRI Tahun 2014 Nomor 292, TLNRI Nomor 5601) 